\section{Changeover at Mt. Stromlo}

Professor Olin J. Eggen has now taken up his new post as Director of the Mt. Stromlo Observatory, Canberra. He succeeds Professor Bart Bok, who has been at Mt. Stromlo since 1957 and who has now become Professor of Astronomy at the University of Arizona. Eggen, who is an American by origin, started his distinguished career at Lick Observatory. From there he moved to Canberra when Sir (then Dr.) Richard Woolley was director and when the 74-in. telescope was being built. Since the mid-fifties Eggen has moved between the Royal Greenwich Observatory (which is not at Greenwich but at Herstmonceux) and Pasadena in California. For a time he was assistant to the Astronomer Royal at Greenwich.

Eggen is an astrophysicist who has spent much of his time making photometric observations and has studied motions of stars within our galaxy. He has said in Australia that he intends to concentrate the work of the observatory at Mt. Stromlo on observation and should in this be helped by the care with which Mt. Stromlo is being equipped.

At this stage there is no knowing whether the arrival at Mt. Stromlo of an American astronomer with close connexions in Britain will affect the issue of the Southern Hemisphere telescope. It remains to be decided whether the British Government or the American Government will eventually help with the building of a large telescope (with an aperture of 150 in. or more) in Australia. Astronomers of all nationalities regret the delay there has been.

\section{Railway Relics}

Not only Mr. John Betjeman will be up in arms about the proposal by British Rail to dismantle St. Pancras and Kings Cross Stations, and it is bound to be some time before it is known whether one modern terminal will be built to replace both monuments to the Railway Age. To replace St. Pancras and Kings Cross by a modern terminal would in any case be an unenviable task for the architect chosen, for he could scarcely contrive to improve on their combined merits; the flamboyant self-confidence of St. Pancras, offset by the sterner stuff of Kings Cross. The two buildings epitomize the ambivalence of the Victorian age.

By guile or by accident, however, the railways board has made sure that there will be few technologists among those who will, no doubt, be lying in the road to impede the demolition men. It has been promised that when the soaring Gothic of the station eventually disappears, the arch of the station itself will be exposed for all to sce. The arch was built by William Henry Barlow in the continental style in 1868. The vault is vast, and makes great use of cast iron arches and glass, although less elegantly than John Dobson's Newcastle Central Station of many years earlicr. The icing sugar hotel façade was added in 1874 to the designs of that high-priest of Victorian Gothic, Sir George Gilbert Scott.

It seems churlish to carp at British Rail when their intention is to cut costs and increase efficiency; a more modern approach to the running of the railways is a right and proper end to pursue, but if St. Pancras and Kings Cross follow the steam engine into oblivion, for many the romantic flavour of the railways will be gone for ever.
University News:

The City University

Mr. K. J. SHone has been appointed professor and head of the Department of Management Studies. Mr. M. L. Meyer has been appointed to the second chair of mechanical engineering. Dr. R. N. Cox has been appointed to the second chair of aeronauties. Dr. R. C. Pitkethly has been appointed associate professor in the Department of Chemistry for threo years.

\section{Appointments}

Dr. F. S. DaInTon, vice-chancellor of the University of Nottingham, has been appointed chairman of the advisory committee for Scientific and Technical Information, in succession to Sir James Cook, at present vice-chancellor of the University of Exeter and vice-chancellor designate of the University of East Africa.

DR. C. A. Spoun has been appointed director of operations of the National Environmental Satellite Center, Environmental Science Services Administration, in succession to A. W. Johnson who has been appointed deputy director of the Department of Commerce facility.

Dr. K. O. Wright has been appointed director of the Dominion Astrophysical Observatory at Victoria, B.C., in succession to the late Dr. R. M. Petrie.

\section{Announcements}

THE London office of the National Institutes of Health, U.S. Public Health Service, is being closed as from September 12. The functions of this office will be transferred to the N.I.H. European office in Paris. The research grant, fellowship, and other programmes of N.I.H. in the United Kingdom and other areas will continue as bofore with administrative responsibility consolidated in Paris. Further information can be obtained from Dr. P. G. Condliffe, Chicf European Office, National Institutes of Health, 2 Avenue Gabriel, Paris 8e.

The British Society of Rhoology has instituted a gold medal which will be awarded every three years for "the best contribution to the solution of an industrial problem by the application of fundamental rheological knowledge". The first medal will be awarded next year, and the closing date for entries is May 1, 1967. Further information can be obtained from Mr. A. T. J. Hayward, National Enginecring Laboratory, East Kilbride, Glasgow.

\section{CORRESPONDENCE}

\section{Preprints Galore}

Sir,--Your editorial of August 27 will be read with great interest and many biologists will agree with your statement that "The defects of IEG and PIE are no excuse for hiding from the problems which stimulated their emergence". These problems are to be discussed at a conference on "Communication in the Biological Sciences", to be held during December 14-15, 1966, under the auspices of the Biology Group of Aslib and the Institute of Biology. The organizers hope that this conference will agree on the stcps nceded to deal with the problems of information exchange facing biologists working in laboratory and library. If so, it should guide the various bodies concerned with the publication, dissemination and retricval of information.

$$
\begin{aligned}
& \text { Yours faithfully, } \\
& \text { D. J. B. CopP, } \\
& \text { Gonoral Secretary, }
\end{aligned}
$$

Institute of Biology,

41 Queen's Gate, London, S.W.7. 